\title{
THE FUNEREAL BOREAL OWL
}

J. STAN ROWE, 18 Kirk Crescent, Saskatoon, Saskatchewan. S7H $3 B 2$

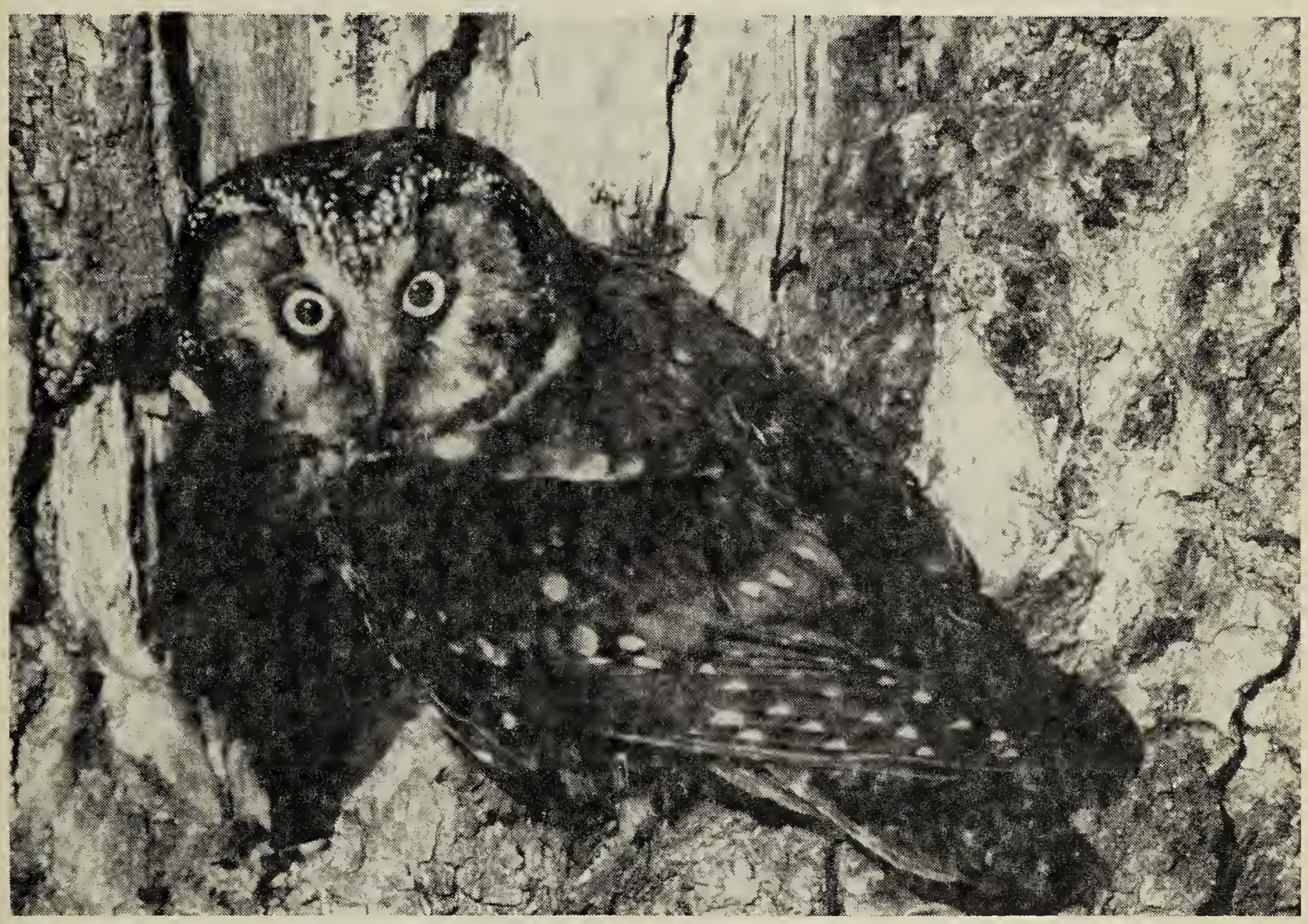

Boreal OWl

R.E. Gehlert

Strange how the poet, striking words together, ignites the imagination. Just so Anne Szumigalski, with her poem The Farm, has set aprowl in my mind the Boreal Owl. ${ }^{9}$ By what intuition did she link him to death in the city and life in the woods?

"night cries which once were owls in the woodlot have become the calls of an ambulance tearing through the streets to the morgue what's the hurry asks the corpse in a gentle voice the driver-paramedic doesn't have an answer".

And at the end

".. he wonders could it have been his own in some other place full of rural temptations where a log hut backs on the forest the one window looking over a small barnyard and beyond that a couple of ploughed fields there on winter nights the boreal owl hunts mice in the furrows". 
The reference by a Saskatchewan poet to the Boreal Owl, cousin of the European Tengmalm's Owl to which Linnaeus gave the name Aegolius funereus, is apt. As Canadian as spruce groves and black flies, its year-round range coincides closely with our northern forests although recently it has been discovered nesting at high altitudes south of the border where, too, it is periodically "eruptive". ${ }^{8}$ Returning from the Second Franklin Arctic Expedition, Dr. John Richardson in 1827 collected a first specimen of the American subspecies near Fort Carlton, Saskatchewan, commemorated by Bonaparte in the trinomial Aegolius funereus richardsoni. ${ }^{3}$

The generic name Aegolius - of uncertain Greek origin but applied by Aristotle to one kind of ow $\left.\right|^{2}$ - bespeaks the classical training of Linneaus but little else. More intriguing is the descriptive synonym Cryptoglaux used by some ornithologists, meaning the secretive or hidden (because nocturnal) little owl, "glaux", from its fierce, glaring eyes. ${ }^{4} 107$ When Homer described Pallas Athene (Minerva of the Romans) as "glaucopis" he probably meant flashing-eyed, the goddess sharing this startling ocular attribute, as well as wisdom and sagacity, with her feathered emblem the owl. ${ }^{7}$

The specific name funereus (or funerea when paired with Cryptoglaux) means "funereal"; an allusion to the owl's haunting call "as if wailing the dead". ${ }^{2}$ This may be an imaginative generalization for all the owl tribe, whose members since Roman times have been regarded as portents of evil and death; mysterious, sinister, like ambulance wails in the night. With the exception of the Barn Owl, all species are assigned to the Strigidae, the strident screechers. The very word "owl" is the echoic base of ululate, meaning to mourn or lament. Obviously howls come from owls. But is this the voice of the Boreal Owl; does its cry justify the grave and somber specific name? My fragmentary ornithological library is equivocal.
Taverner pronounces it a "good" owl (it eats mice) but concerning its call he is mute and gives no hoot. ${ }^{10}$ Vogt says the voice of the Boreal Owl is a liquid note like dripping water. ${ }^{1}$ According to Peterson its song is like a soft high-pitched bell or dropping of water (Bent), and also it has a harsh grating call. ${ }^{6}$ Seton says its voice goes "Ting, ting, ting". 5 Dr. Merriam describes the call as a "low liquid note that resembles the sound produced by water dropping from a height; hence the Montagnais Indians call it phillip-piletschch, which means "water dripping owl". " According to their folklore, he says, the Great Spirit humbled the owl in size and reduced its great voice to a slow feeble drip when it impertinently imitated the sound of a cataract and tried to drown out its roar. But Scott says its call, heard only in the breeding season, is a short series of rapid hollow hoo notes. ${ }^{8}$ Will the real Boreal Owl please speak up?

Clearly a consensus is lacking. Although the hoot of Aegolius seems to be moot, the composite picture that emerges from my mostly American bird books is that of an amiable little owl, a bit of a dickey owl (Richard = Dick, richard soni $=$ dickey), a sort of rotund nocturnal hermit thrush making sounds of tinkling water in the wasteland, "very tame", decidedly unfunereal and most certainly not a poet's kind of bird. Did Linnaeus, then, err in its naming?

To the rescue comes the Saskatchewan team of Houston and Street, charitably saving the bad name of the Boreal Owl. ${ }^{3}$ According to them, Richardson (surely the authority on a bird saddled with his moniker) reported the night cry of Aegolius funereus richardsoni as a single melancholy note, repeated at intervals of a minute or two. Furthermore, he said, the Cree Indians call it cheepaipeethees, the Death-bird, and to them its nocturnal hootings are particularly ominous. When they hear its note, they never fail to whistle, and if it does not reply to the whistle by its hootings, the 
speedy death of the inquirer is augured (my emphasis).

This local variation of Russian roulette - which incidentally is a promising method of population control, for it selectively eliminates male whistlers - must have perpetually decimated the ranks of the Cree, for Richardson went on to report that the owl is so common on the banks of the Saskatchewan River that its voice is heard by the traveller wherever he selects his bivouac. Nevertheless, few even of the hunters have seen the Deathbird, he said, for it never appears in the day. ${ }^{3}$

And so, happily, the name funereus is fitting. Though continents apart and unknown to each other, the Cree Indians vindicated that old artist Linnaeus as he vindicated them. Whether in Sweden or in Canada, whether called the classic Greek Aegolius or the classic Cree Cheepaipeethees, the Boreal Owl by concensus of northern taxonomists is funereal.

I feel better for that. And a deeper appreciation of one member of the local fauna gives me greater empathy with Anne Szumigalski's driver-paramedic and his dream-Farm. Regionally minded, I place him now in Prince Albert, where night cries that once were owls in the woodlot have become the calls of an ambulance tearing through the streets to the morgue. Away from the bright lights, somewhere on the river between Fort Carleton and Cumberland House, a log hut at the old farmstead backs on the forest; there on winter nights the Boreal Owl hunts mice in the furrows.

Despite rural temptations, relative safety and security reign at The Farm on those long winter nights, far from the city. But beware the return of spring and with it the breeding season of (Aegolius) Cryptoglaux funerea richardsoni. When, up and down the Saskatchewan River, the melancholy owl is heard once again in the gloom, let him who dares mimic its call.
Thank you Mary Gilliland for providing references numbered 2 and 7 .

' AUDUBON, J.J. 1937. The Birds of America, with descriptive captions by $W$. Vogt. New York. The MacMillan Company. 435 $\mathrm{pp}$.

${ }^{2}$ GRUSON, E.S. 1972. Words for Birds: a lexicon of North American birds with biographical notes. New York. Quadrangle Books. 305 pp.

${ }^{3}$ HOUSTON C.S. and M.G. STREET 1959. The Birds of the Saskatchewan River: Carleton to Cumberland. Spec. Publ. No. 2, Sask. Nat. Hist. Soc. 205 pp.

${ }^{4}$ PEARSON, T.G. (Ed.) 1936. Birds of America. Garden City, New York. Garden City Books. Part II. 271 pp.

${ }^{5}$ PETERSON, R.T. 1947. A Field Guide to the Birds: giving field marks of all species found east of the Rockies. 2nd edition. Boston. Houghton Mifflin Co., Cambridge. The Riverside Press. 290 pp.

${ }^{6}$ PETERSON, R.T. 1961. A Field Guide to Western Birds, 2nd edition. Boston, Houghton Mifflin Co. 309 pp.

${ }^{7}$ ROWLAND, B. 1978. Birds with Human Souls; a guide to bird symbolism. Knoxville, Tennessee. University of Tennessee Press. 213 pp.

${ }^{8}$ SCOTT, S.L. (Ed.), 1983. Field Guide to the Birds of North America. National Geographic Society, Washington, D.C. 464 pp.

${ }^{9}$ SZUMIGALSKI, A. 1983. The Farm. Doctrine of Signatures. Saskatoon, Saskatchewan. Fifth House. 99 pp.

10 TAVERNER, P.A. 1926. Birds of Western Canada. Museum Bulletin No. 41, Victorial Memorial Museum, Canada Department of Mines, Ottawa. The King's Printer. $380 \mathrm{pp}$. 